\title{
Descriptive Anatomy of Hepatic and Portal Veins with Special Reference to Biliary Duct System in Broiler Chickens (Gallus gallus domesticus): A Recent Illustration
}

mAuthor(s)

Maher MA' (iD) https://orcid.org/0000-0002-7040-7813

\section{-Mail Address}

Corresponding author e-mail address M A Maher

Vet Medicin Cairo University, Faculty of Veterinary Medicine, Ringgold Standard Institution, Cairo University, Cairo, 12411, Egypt.

Phone: (+20) 01069951919

Email: dr.maher85@yahoo.com

\section{nKeywords}

Biliary system, Chicken, Hepatic vein, Intrahepatic and Porta vein

\section{ABSTRACT}

Chickens have a great participation in meat and egg production. The anatomical scientific data of poultry is important to support the recent researches either for illustrations in academic studies or clinically in diagnosis and treatment of some poultry nutritional diseases. The current investigation was performed on twenty broiler chickens of both sexes. The chickens were anaesthetized, slaughtered then the venous system was flushed with a normal saline to anatomically investigate the distribution of hepatic portal veins both intra and extrahepatic, as well as the hepatic venous and biliary duct systems. The fowl had two hepatic portal veins draining the gastrointestinal tract with its associated organs as spleen and pancreas. The left hepatic portal vein was small, restricted to a limited portion of left hepatic lobe and had been constituted by five main venous tributaries draining the proventriculus, gizzard and pylorus, while the right hepatic portal vein was the largest, receiving the proventriculosplenic, gastropancreaticoduodenal and common mesenteric veins then piercing the right hepatic lobe to be distributed in both hepatic segments through right and left divisions. The fowl has two hepatic portal veins differed in size and distribution. A characteristic imaginary trapezoid shape was formed by some tributaries draining the caudoventral part of the gizzard. There are three ileocecal veins; cranial, caudal and the ileocecal tributary of the cranial mesenteric vein. The wall of gall bladder and the common hepatoenteric duct was characterized by the presence of well-defined longitudinal folds or striations.

\section{INTRODUCTION}

The chickens (Gallus gallus domesticus) belong to family Phasianidae, are the most common consumed species of poultry in the world regardless of beliefs (Roenigk, 1999; Aho, 2001; Aho, 2004). Chicken products are considered as very important source of protein all over the world. Chickens for meat represent about $70 \%$ of human consumption, Turkeys about $8 \%$ and other poultry about $22 \%$ of the total consumption (Roenigk, 1999; USDA, 2006; Al-Nasser et al., 2007).

The fowl liver, as in all vertebrates, is considered the largest gland in the body possessing an excretory function through a duct system and an endocrine secretion directly into the blood (McLelland, 1989). Anatomically, bird liver is bi-lobed, right and left which are connected anteriorly at midpoint. The right lobe is larger in the domestic fowl and the left lobe is subdivided into the dorsal and ventral parts (Whitlow, 2000; Caceci, 2006; Al-A'Aaraji, 2015). The liver function can be divided into; vascular functions as storage and blood filtration, secretory function as producing bile to the digestive tube which is necessary for the emulsification of fats and metabolic function of carbohydrates, proteins 


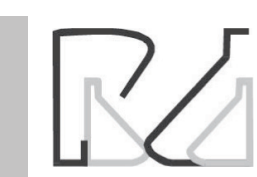

and fats. The composition of bird bile is similar to mammals and their excretion can be performed directly to the duodenum or stored in the gallbladder Kolb (1984). The biliary ducts and blood vessels penetrate the liver into a transverse cleft on the visceral surface and the fusiform gallbladder is present in the chicken, duck and goose while absent in the pigeon Dukes et al. (1996). The right portal hepatic vein drains blood from the stomach, duodenum, pancreas and ileocecal portions through the gastropancreaticoduodenal vein, and the jejunum, ileum and cecum through the cranial mesenteric vein. The left portal hepatic vein drains the blood from parts of the stomach through the pyloric vein, left gastric vein, ventral gastric vein, caudal and proventricular veins Baumel et al. (1979).

There are a lot of records related to the anatomy of mammalian hepatic vasculature, either intra or extrahepatic distribution of veins and biliary duct system, but only few superficial anatomical reports in the avian species especially, the chickens. The current study aimed to illustrate a more anatomical description of both intra and extrahepatic distribution of the portal and hepatic veins as well, the biliary duct system of chickens and to point out its variability from those of mammals. This may provide a recent support and adequate anatomical guide and basis for the practical research of the portal and hepatic blood flow in addition to bile distribution in the domestic fowl.

\section{MATERIALS AND METHODS}

Experimental Design: The present work was performed on apparently healthy twenty broiler chickens of both sexes obtained from local distributors in the market near the area of Giza, Egypt. Before slaughtering, intra-muscular anaesthetization using xylazine $\mathrm{HCL}$ was performed for relaxation and to prevent vasoconstriction, in addition to an anticoagulant agent as heparin in wing vein to keep blood especially of liver and gastrointestinal tract without clotting.

Research Tools and Procedure: Each broiler chicken was then slaughtered and left for evacuation of large amount of blood, and then a transverse incision was taken below the sternum and thoracic cage to expose the liver, spleen and gastrointestinal tract. The portal and hepatic veins were flushed with normal saline solution. Two techniques of injections were applied to illustrate the normal distribution of portal vein, hepatic veins and biliary duct system. The latex technique in which the chickens were inoculated with
Descriptive Anatomy of Hepatic and Portal Veins with Special Reference to Biliary Duct System in Broiler Chickens (Gallus gallus domesticus): A Recent Illustration

$60 \%$ gum milk blue-colored latex with Rotring ${ }^{\circledR}$ ink was used to illustrate the portal vein and the corrosion cast technique in which (KEMAPOXY 150 2A/1B) obtained from chemical modern building $(C M B)$ mixed together in ratio of $2 \mathrm{~A}: 1 \mathrm{~B}$ then injected immediately before solidification after adding the white color was used to illustrate the hepatic veins and green color for the biliary duct system.

Parameters Measured: The results obtained were photographed using a digital photo camera Nikon COOLPIX L310 14.1 Megapixels in 10 photographs. The nomenclature used was according to Nomina Anatomica Avium $^{13}$ and those mentioned by the previous literatures.

\section{RESULTS}

The liver of fowl is located in the cranial portion of the body cavity having its shape accommodated to the surrounding internal body wall and related structures such as the proventriculus, gizzard, spleen, gall bladder and the intestinal loops which all participate in the characteristic contour and depressions of the liver. The liver has a clear transverse cleft or groove on the visceral surface of both liver lobes which reveal the entrance of the large portal veins, hepatic arteries, the two emerging bile ducts and the well-defined fusiform gall bladder. It was found that the right lobe of liver was larger than the left one and undivided while the left lobe was nearly smaller and divided into dorsal and ventral divisions.

\section{Extrahepatic vessels (Portal veins tribu- taries)}

Vv. Portae Hepatis: The hepatic portal systemin fowls was observed to have two portal veins; the right hepatic portal vein (fig. 3, 7, 8/3) is the largest which enter the liver through the right lobe, and the left hepatic portal vein (fig. $1,7,8 / 24$ ) which is smaller and situated on the dorsal division of the left lobe of the liver.

V. Portae Sinistrae Hepatis: The left hepatic portal vein (fig. $1,7,8 / 24$ ) was a small vessel measuring about $2 \mathrm{~cm}$. It was located on the visceral surface of left dorsal lobe of the liver and at a midpoint between the isthmus gastris (fig. 1/c) and the sulcus cranialis of the gizzard (fig. 2/A/g) where it received the following five well-defined venous tributaries:

Vv. proventriculares ventralis: The ventral proventricular veins (fig. 1, 2/25) are 4-5 small veins draining blood from the ventral and left ventrolateral aspects of the proventriculus. These veins present at opposite side to $v$. gastricaglandulariscranialis (fig. 


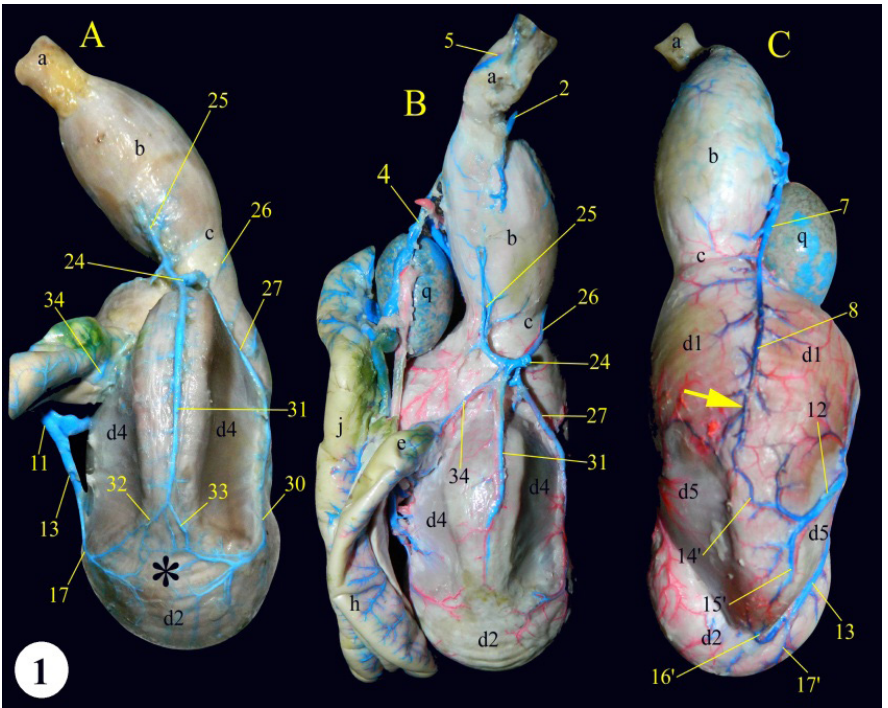

Figure 1 - Gross anatomical photograph showing extrahepatic tributaries of left hepatic portal vein in broiler chicken. $(A, B)$ ventral view and $(C)$ dorsal view of stomach.

${ }^{*}$ ) Trapezoid shape.

1/B/2) which come from the left cranial vena cavathen pour blood into the left hepatic portal vein.

V. proventricularis sinistra: The left proventricular vein (fig. 2/26) was one or two fine tributaries of the left hepatic portal vein located at the isthmus gastris and receive blood from the left aspect of the isthmus as well as the left caudal portion of the proventriculus and the cranial portion of the gizzard then open into the left gastric vein (fig. 2/A/27) or into the left hepatic portal vein directly.

V. gastrica muscularis sinistra: The left gastric vein (fig. 1,2/27) is the largest of them, draining all the components of the left aspect of the muscular stomach "gizzard". It was formed mainly by three smaller tributaries; the dorsal one (fig. 2/28), running at the sulcus cranialis draining the $M$. tenuis craniodorsalis, the intermediate one (fig. 2/29), divided into two twigs, one coursing through the sulcus caudalis and the other one draining the $\mathrm{M}$. crassuscaudorsalis and the ventral tributary (fig. 2/30), draining both the $\mathrm{M}$. tenuis caudoventralis and the $\mathrm{M}$. crassuscranioventralis and participating in formation of trapezoid shape (fig. $1 /^{*}$ ) with the tributaries of $v$. gastrica muscularis ventralis (fig. 1, 2/31).

V. gastrica muscularis ventralis: The ventral gastric vein (fig. 1, 2/31) was situated along the whole length of the ventral border of the muscular stomach at midline taking its convexity where its cranial end open with the left hepatic portal vein while its caudal end collecting blood through two diverging right and left small twigs (fig. 1/A/32, 33) which anastomosed with each ventral tributary of the left gastric vein forming a trapezoid frame.

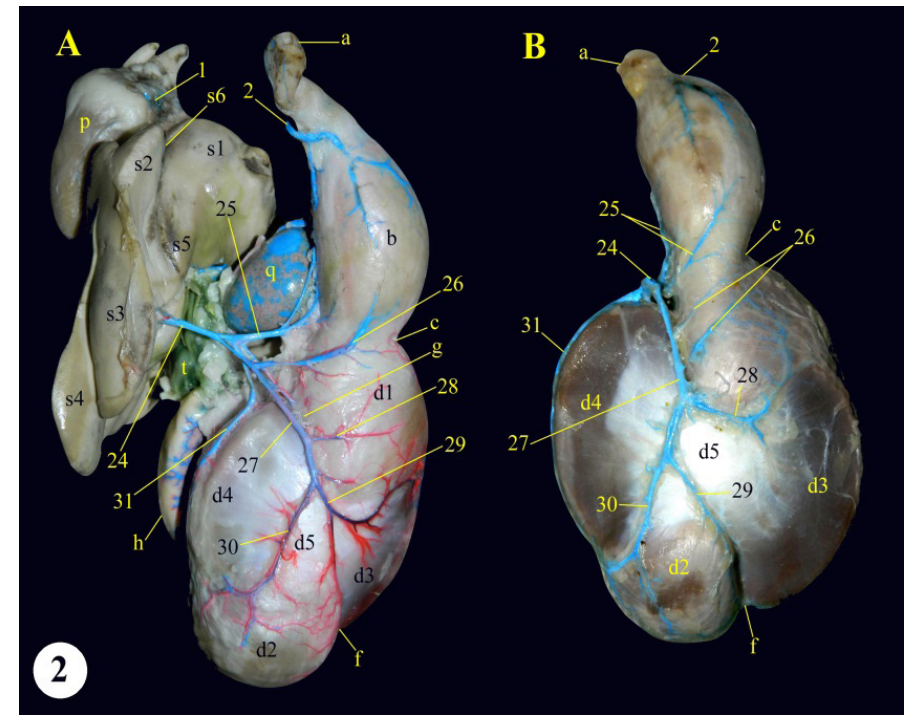

Figure 2 - Gross anatomical photograph showing extrahepatic tributaries of left hepatic portal vein in broiler chicken. $(A, B)$ left views of stomach.

V. pylorica: The pyloric vein (fig. 1/B/34) was the only venous tributary located on the right side of the muscular stomach. It descends oblique cranioventrally draining the pylorus and first small portion of descending duodenum untill reaching the left hepatic portal vein.

V. Portae Dextrae Hepatis: The right hepatic portal vein (fig. 3, 7, 8/3) was the largest tributary of the portal vein. The length from its formation by extrahepatic tributaries untill its entrance at the porta hepatis was about $3 \mathrm{~cm}$. It received blood from the proventriculosplenic, splenic, gastropancreaticoduodenal and common mesenteric veins.

V. Proventriculosplenica: The proventriculosplenic vein (fig. 3,5/4) was the first and or the nearest venous tributary of the right hepatic portal vein passing between the spleen caudally and most of the upper part of the right lobe of the liver cranially. It received small tributaries early coming from the spleen while the tributaries coming from the proventriculus were varied here where the specimens were divided equally, $50 \%$ of the cases showing only fine small twigs distributed on the right and dorsal aspects of the proventriculus called dorsal proventricular veins (vv. proventriculares dorsalis) (fig. 3, 4, 5/6) and the other $50 \%$ of cases showing the dorsal proventricular veins as well as another branch draining the dorsal aspect of the muscular stomach called dorsal gastric branch (r. gastrica muscularis dorsalis) (fig. 1/c/8) (fig. 3, 4/B/8) which was anastomosed with the dorsal branch of the right gastric vein (fig. 1/c/14' and yellow arrow) and continued toward the proventriculus where changed to be right proventricular vein (v. proventricularisdextra) 


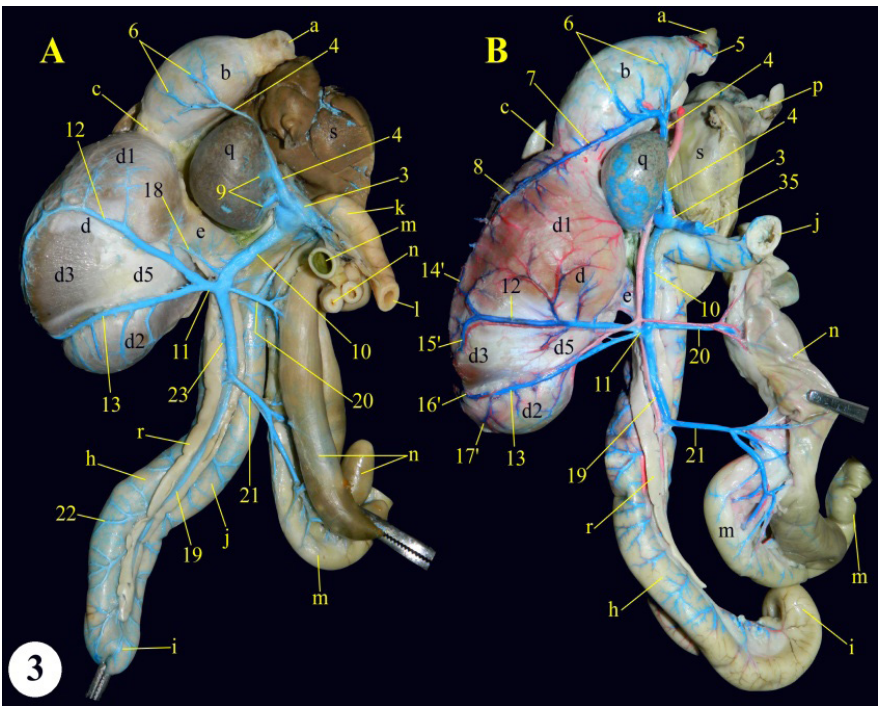

Figure 3 - Gross anatomical photograph showing extrahepatic tributaries of right hepatic portal vein in broiler chicken. $(A, B)$ right views of some digestive organs.

(fig. 1//7) (fig. 3, 4/B/7) and united with the dorsal proventricular vein forming the proventriculosplenic vein. While the proximal part of proventriculus was drained through the cranial proventricular vein ( $\mathrm{V}$. gastricaglandulariscranialis) (fig. 2/A/2) which runs forward along the esophagus receiving (R. esophgeus) (fig. 1/B/5) and empties directly into the venous sinus, not joining the portal system.

Vv. Splenicae: The splenic veins (fig. 3, 5/9) in fowl were two or three short small separated veins measuring about $0.4 \mathrm{~cm}$ in length emerging at the splenic hilus where it drained the splenic parenchyma and the splenic capsule then entering the proventriculosplenic vein at a perpendicular position where participating in its formation.

V. Gastropancreatico duodenalis: The gastropancreatico duodenal vein (fig. 3, 4, 5/10) was a long and great cylindrical venous tributary measuring about 4-5 $\mathrm{cm}$ in length and entering the right hepatic portal vein at an opposite side to the proventriculos plenic vein. It is formed mainly by three main tributaries at the same point of entrance, the short stout right gastric vein (fig. 5/11) from right side, the cranial ileocecal vein (fig. 3/20) from left side and the pancreaticoduodenal vein (fig. 3/19) which considered as its caudal continuation. Along its course, the gastropancreaticoduodenal vein received pyloric fine twigs (fig. 3, 4/A/18) and some duodenal venules from the ascending duodenum.

V. Gastrica Muscularis Dextra: The right gastric vein (fig. 3/11) was very short, measuring about 0.3 $0.5 \mathrm{~cm}$ in length and open directly in a perpendicular manner in the gastropancreaticoduodenal vein. It received two long venous tributaries running through the sulcus cranialis and sulcus caudalis on the right

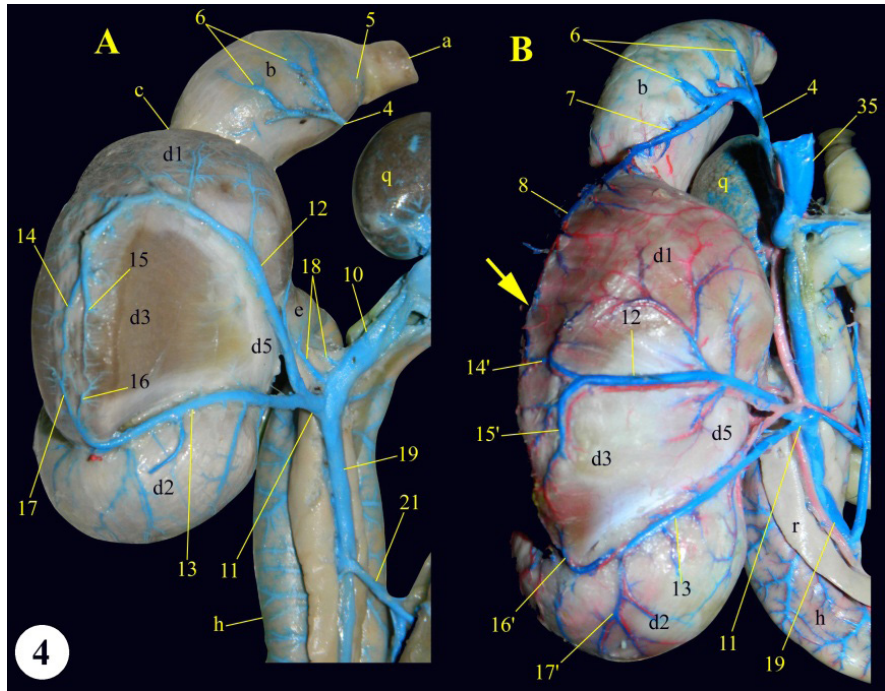

Figure 4 - Gross anatomical photograph showing extrahepatic tributaries of right hepatic portal vein in broiler chicken. $(A, B)$ right views of some digestive organs.

aspect of the muscular stomach which were the dorsal branch (fig. 3, 4/12) and ventral branch (fig. 3, 4/13) of the right gastric vein respectively. The dorsal and ventral branches of the right gastric vein had a characteristic acute angle along its course till being met and forming the short right gastric vein while their terminal ends toward the dorsal aspect of the gizzard had some variations between the investigated specimens. In 50\% of the cases, the terminal end of the dorsal and ventral branches were divided into right and left venules (fig. $4 / \mathrm{A} / 14,15,16,17)$ which anastomosed with each other while in $50 \%$ of the cases, the terminal ends were divided into cranial and caudal venules (fig. 3, $4 / B / 14^{\prime}, 15^{\prime}, 16^{\prime}, 17^{\prime}$ ) where the cranial venule of the dorsal branch anastomosed with the R. gastrica muscularis dorsalis of proventriculosplenic vein (fig. $1 /$ c/yellow arrow) and the caudal venule anastomosed with the cranial venule of the ventral branch of right gastric vein while the caudal venule of the ventral branch participating in the formation of the trapezoid shape with the $V$. gastrica muscularis ventralis and $V$. gastrica muscularis sinistra to drain the $M$. tenuis caudoventralis. Along their course through the mine sulcus, the dorsal and ventral branch of the right gastric vein received fine tributaries draining the cranioventral and caudodorsal muscle crassus, the cranioventral and caudodorsal muscle tenuis as well as the centrum tendineum.

V. Pancreaticoduodenalis: The pancreaticoduodenal vein (fig. 3, 4/19) was the largest venous tributary of the gastropancreaticoduodenal vein due to its size and considered as the direct continuation of the gastropancreaticoduodenal vein measuring about 12 $15 \mathrm{~cm}$ in length. It passed in between the descending 
and ascending limbs of anastomosed duodenum enclosed and in some areas being hidden by the pancreatic lobules and within the mesoduodenum. Along its course, it received Vv. Pancreaticae (fig. 3/A/23) that drained venous blood from the pancreas, $\mathrm{Vv}$. duodenales (fig. 3/A/22) draining parts of duodenum and $\mathrm{V}$. Ileocecalis caudalis (fig.3/21) receiving blood from initial part of the ileum and the proximal blind half of the two ceci through 8-10 small twigs.

V. Ileocecalis: The fowl had three ileocecal veins of two different draining origins, the cranial ileocecal vein (fig. 3/20) that drained the caudal terminal portion of the ileum and the distal half of the two ceci near the colorectum through 5-6 small twigs which ended by entering the gastropancreaticoduodenal vein while the caudal ileocecal vein (fig. 3/21) was one of the tributaries of the pancreaticoduodenal vein and finally, the ileocecal veins of cranial mesenteric vein (fig.6/39).

V. Mesenterica Communis: The common mesenteric vein (fig. 5, 6/35) was the largest of them with a mean length of $6-8 \mathrm{~cm}$. It was formed mainly by the union of two great veins at the duodenojejunal flexure, the cranial mesenteric and the caudal mesenteric veins.

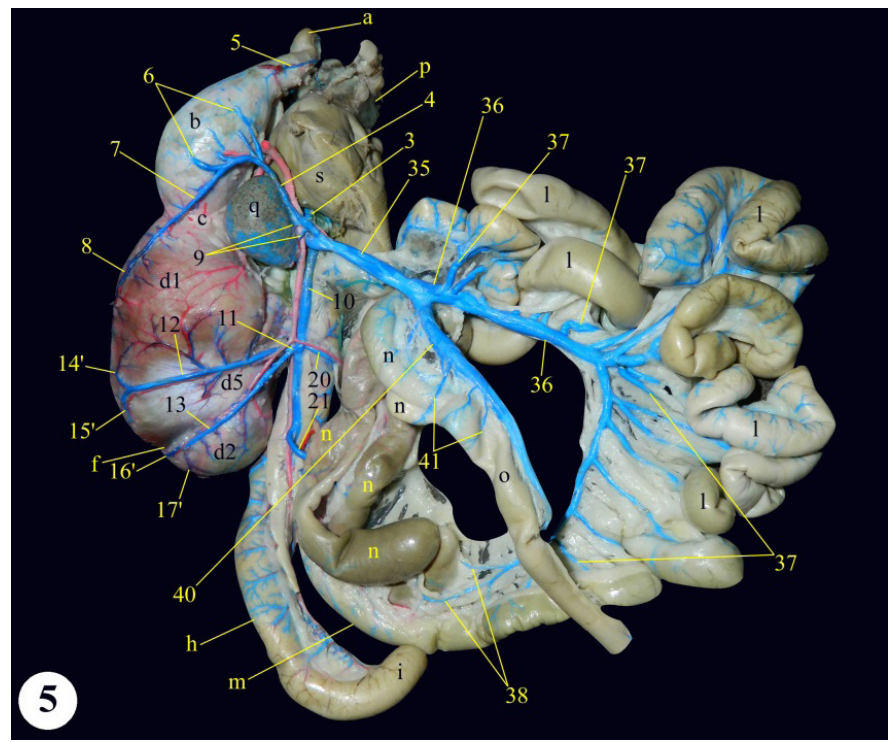

Figure $\mathbf{5}$ - Gross anatomical photograph showing extrahepatic tributaries of right hepatic portal vein in broiler chicken gastrointestinal tract.

V. Mesenterica Cranialis: The cranial mesenteric vein (fig. 5, 6/36) was the main vein that drained the greater portion of small intestine from the duodenojejunal flexture to the terminal parts of ileum and cecum. It was formed by $\mathrm{V} v$. Jejunales that drained all the jejunal coils, $V v$. Ileae that drained the initial portions of ileum and finally the $V$. Ileocecalis that drained the middle portions of ileum and cecum.

Vv. Jejunales: The jejunal veins (fig.5,6/37) in fowl were about 22-25 in number and radiated from the jejunal wall and directed toward the cranial mesenteric vein in a parallel manner. The first two jejunal veins collected 3-5 smaller veins draining the duodenojejunal flexture.

Vv. Ileae: The ileal veins (fig. 5/38) were two terminal fine tributaries of the cranial mesenteric vein in between the initial part of the ileum and the two blunt blind ends of the two ceci where the ileal veins drained the related area of the ileum then ended at the blunt ends of cecum then fused to contribute in the formation of the cranial mesenteric vein along with the jejunal veins.

V. Ileocecalis: The ileocecal vein (fig. 6/39) was the third venous tributary that joined the cranial mesenteric vein from its ventral aspect and at the point of fusion of the cranial and caudal mesenteric veins to form the common mesenteric vein. It drained the middle portion of both the ileum and the two ceci through 3-4 smaller veins (fig. 6/39', 39").

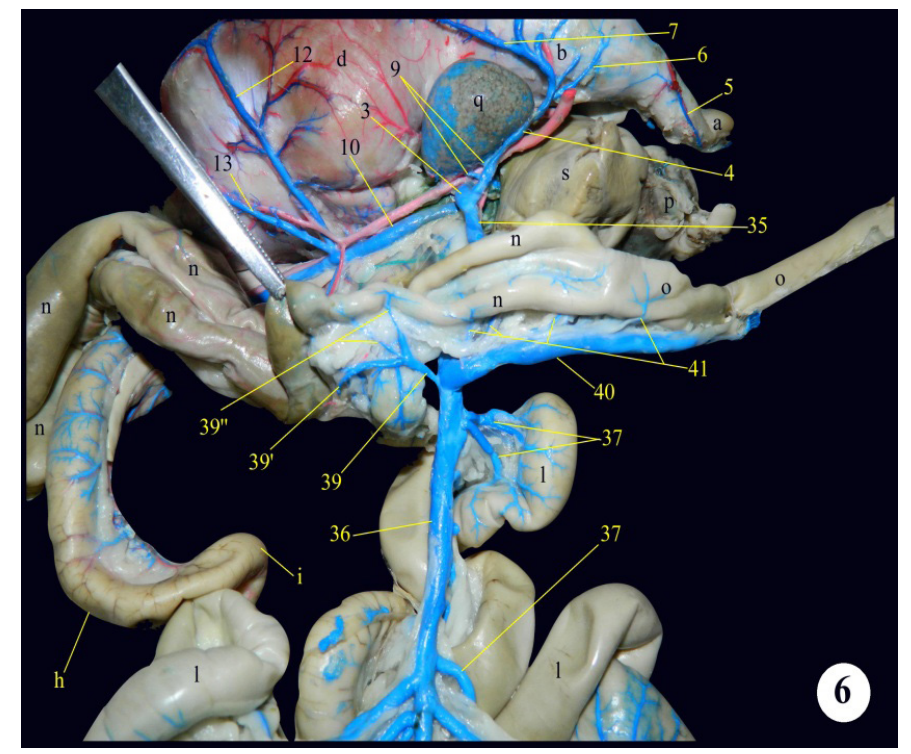

Figure $\mathbf{6}$ - Gross anatomical photograph showing union of common mesenteric vein in broiler chicken.

V. Mesenterica Caudalis: The caudal mesenteric vein (fig. $5,6 / 40$ ) in fowl was large and long measuring about $14 \mathrm{~cm}$ in length running through the whole length from cloaca, colorectum and the ileocecal connection till united with cranial mesenteric vein forming the common mesenteric vein. The caudal mesenteric vein had cranial and caudal tributaries. The cranial tributaries (Rdx. cranialis cum v. mesentericacaudalis) (fig. 6/41) of the caudal mesenteric vein drained the terminal portions of the ileum and two ceci as well as the initial few centimeters of the colorectum through 6-8 fine tributaries which anastomosed cranially with the cranial mesenteric vein indirectly. 


\section{Intrahepatic vessels (Portal veins-Hepatic veins-Biliary system)}

Intrahepatic Portal veins distribution: The intrahepatic portal system in fowl was observed to be constituted of two hepatic portal veins differed in their caliber size and admittance through the portal fissure.

The right hepatic portal vein: the largest in size, formed by fusion of proventriculosplenic, gastropancreaticoduodenal and common mesenteric veins then entering the liver at the midpoint of the visceral surface of the right hepatic lobe and related ventrally and resting on the neck of the gall bladder (fig. 7/t). The right hepatic portal vein continued unbranched about $1 \mathrm{~cm}$ toward the parietal surface of the liver through the intrahepatic parenchyma then divided into two divisions, the right (fig. 7,8/42) and left (fig. $7,8 / 45$ ) branches of the right hepatic portal vein. The right branch of the right hepatic portal vein was divided shortly without coursing within the hepatic parenchyma into two large dorsal (fig. 7, 8/43) and two large ventral (fig. 7, 8/44) branches which radiated and further branched into terminal and preterminal smaller twigs distributed all over the parenchyma of the right lobe. The left branch of the right hepatic portal vein was directed and coursed medially toward the left lobe through the hepatic cleft and parenchyma to constitute a transverse part called (pars transversa). The pars transversa (fig. 7, 8/46) was the continuation of the left branch of the right hepatic portal vein which branched at the middle hepatic portion in the parenchyma connecting the right and left hepatic lobes into the median dorsal branches (fig. $7,8 / 47$ ) and ventral median branches (fig. 7/48) and up on reaching the middle of left lobe above the ventral

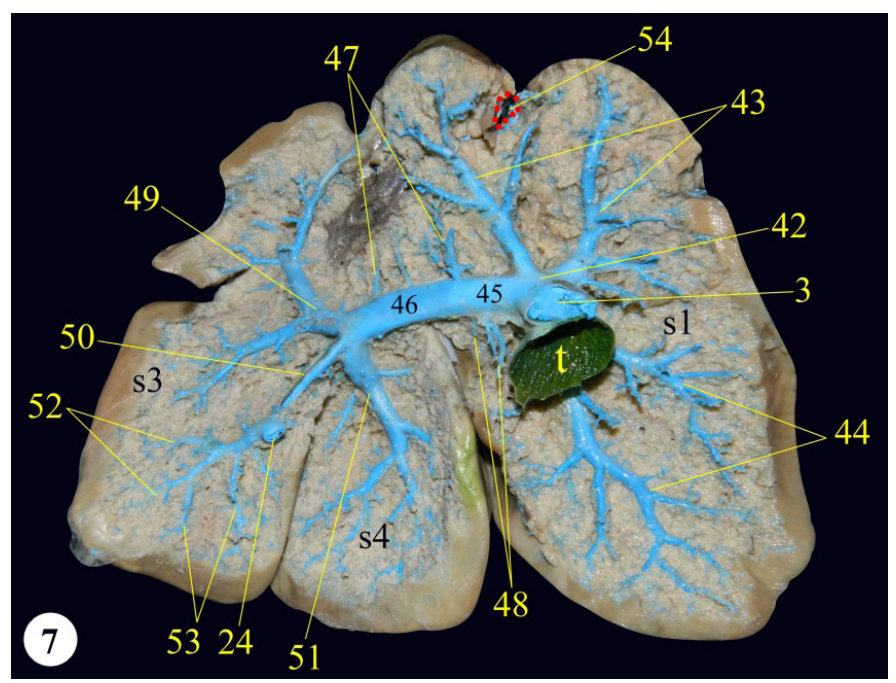

Figure 7 - Gross anatomical photograph of fowl liver showing intrahepatic distribution of right and left hepatic portal veins. fissure dividing the left lobe into dorsal and ventral divisions, the pars transversa was terminated into three well-defined branches, the dorsal branch (fig.7,8/49) that divided into two smaller veins supplying the middle and upper third of the left dorsal division of the left lobe, the ventral branch (fig. 7, 8/51) that further distributed in all directions in the left ventral division of the left lobe and finally, the middle emerged anastomotic branch (fig. $7,8 / 50$ ) that considered the terminal branch anastomosing with the left hepatic portal vein (fig. 7, 8/24).

The left hepatic portal vein: The left hepatic portal vein (fig. $7,8 / 24$ ) in fowl was very small compared to the right one. It drained the highly nutritive nonoxygenated blood from the proventriculus and gizzard through five main tributaries, the ventral proventricular, left proventricular, left gastric, ventral gastric and pyloric veins. After its formation, the left hepatic portal vein gained entrance to the liver through the lower third of the dorsal division of the left lobe few millimeters parallel to the ventral fissure dividing the left lobe. Its intrahepatic ramification was restricted to only 3-5 small fine lateral (fig. 7, 8/52) and ventral (fig. $7,8 / 53$ ) branches that drained the most distal third of the dorsal division of the left lobe of liver.

The hepatic veins: The right and left hepatic portal veins ramified at the porta hepatis and directed to the periphery while the hepatic venous system directed from periphery to the deeper intrahepatic parenchyma toward the porta hepatis. However, the distribution and course of both the portal veins and hepatic veins were irregular, but their main stems were roughly parallel, interdigitate and in contact to each other. The

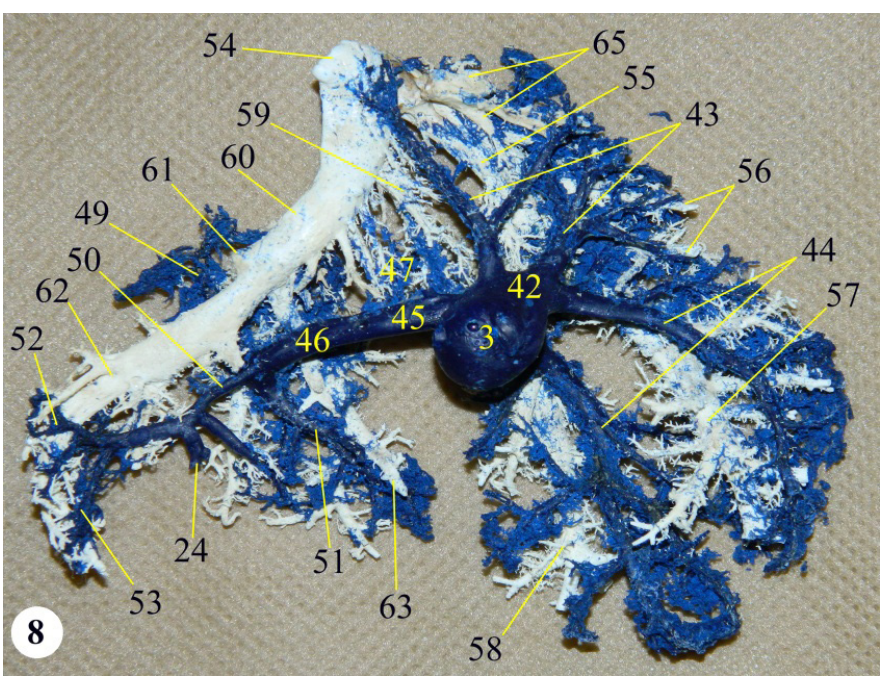

Figure 8 - Gross anatomical photograph of liver cast of fowl showing intrahepatic distribution of right and left hepatic portal veins as well as the hepatic veins (visceral view). 
venous drainage of the caudal part of the body was collected by the caudal vena cava (fig. 7, 8, 9, 10/54) that piercing the dorsomedial portion of the right hepatic lobe to reach the heart (fig. 7/54), but within the liver it received the right, middle (fig. 9, 10/59) and left hepatic veins. Both the right (fig. 9, 10/55) and left (fig. 9, 10/60) hepatic veins received the highly radiated terminal and pre-terminal fine twigs which were dorsocranial (fig. 9, 10/56, 61), dorsocaudal (fig. 9, 10/57, 62) and ventral (fig. 9, 10/58,63) tributaries that drained these portions of the right and left hepatic lobes in addition to the accessory hepatic vein (fig. 10/65) drained into the right hepatic vein and the umbilical vein (fig. 9, 10/64) drained into the left hepatic vein.

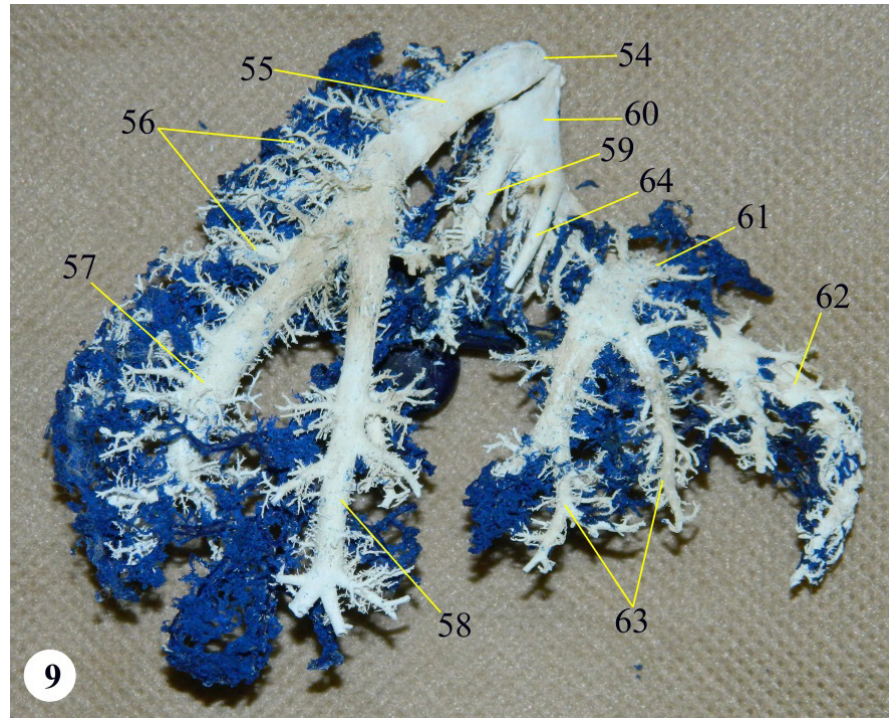

Figure 9 - Gross anatomical photograph of liver cast of fowl showing intrahepatic distribution of right and left hepatic portal veins as well as the hepatic veins (parietal view).

The biliary duct system: The hepatobiliary duct system in fowl was represented in an extrahepatic pass way including the common hepatoenteric duct (fig. 10/x), hepatocystic duct (fig. 10/w), gall bladder (fig. 10/t) and the cysticoenteric duct (fig. 10/y) and an intrahepatic pass way including the diffusely distributed hepatic ducts and ductules. The intrahepatic bile ducts were found to be ramified in a characteristic manner, where the left hepatic lobe drained bile through two left hepatic ducts arranged as branched left dorsal (fig. 10/u1) and left ventral (fig. 10/u2) ducts collecting the bile from the left hepatic segments. The right hepatic lobe drained the bile through three main hepatic ducts arranged as well as branched dorsal duct (fig. 10/v1) collecting from the dorsal segment, the middle duct (fig. $10 / \mathrm{v} 2$ ) collecting bile from the middle segment and the ventral duct (fig.10/v3) from the most ventral segment of the right hepatic lobe. It was observed that the left dorsal duct and right dorsal duct fused distally and just above the well-distended common hepatoenteric duct forming a sinus (fig. 10/z). Another observation was that the hepatocystic duct which connects the gall bladder with the hepatic ducts was found between the right middle hepatic duct and the gall bladder and the right ventral hepatic duct separately opened directly into the gall bladder. Externally, there were well defined longitudinal folds or striations on the wall of the gall bladder and the common hepatoenteric duct.

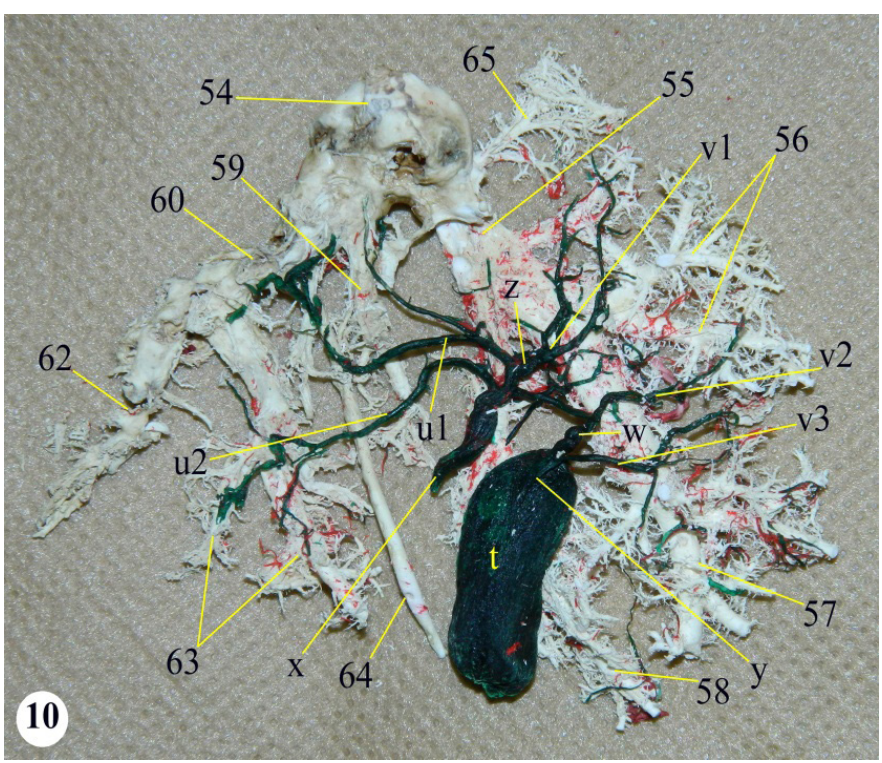

Figure 10 - Gross anatomical photograph of liver cast of fowl showing intrahepatic distribution of hepatic veins and biliary duct system (visceral view).

\section{DISCUSSION}

Our results were in agreement with that observed by Nickel et al. (1977) in domestic birds, Stornelli et al. (2006) in ostrich, Al-A'Aaraji (2015) in turkey, Hussein \& Hussein (2016) in fowl and common moorhen, that the right lobe of the liver was large and undivided while the left lobe was smaller and divided. However, Schmidt et al. (2003) found that the two lobes of chicken liver were equal in size, Ibrahim et al. (2016) in local moorhen noticed that the left lobe of the liver was greater than the right one and Khaleel et al. (2017) had revealed two divisions at the caudal end of the right lobein gulls. A result which not observed in our investigations.

Our investigations revealed that the hepatic portal drainage of fowl was constituted by two large hepatic veins, right and left which was in accordance with the observations of Oliveira (1959) and Malinovsky (1965) in gallus Nickel et al. (1977) in birds, Pinto et al. (1999) in duck, Santos et al. (2009) in geese, El karmoty (2014) in ducks and geese and Tolba (2015) in common domestic pigeons. 
The present investigation was not similar to that reported by Oliveira (1959) and Malinovsky (1965) in gallus who reported that the ventral and left gastric veins with the caudal proventricular vein fused to form the left hepatic portal vein, and of Pinto et al. (1999) in duck who asserted that it formed by one or two left gastric veins, and of El karmoty (2014) in ducks and geese and Tolba (2015) in pigeon who confirmed that only two veins forming the left hepatic portal vein, the ventral proventricular and the left gastric veins. Recently, El Gammal (2016) in turkey and El karmoty \& Tolba (2019) in geese reported three veins forming the left hepatic portal vein, left gastric, ventral gastric and ventral proventricular veins. But, we totally agreed with Nishida et al. (1969) in fowl who revealed that the left hepatic portal vein was constituted by the ventral proventricular, left proventricular, left gastric, ventral gastric and pyloric veins.

Our observations and those of Purton (1969) were not similar to that reported by Pavaux \& Jolly (1968) in chicken, that there was a small additional left portal vein that supplied blood to a limited part of the left lobe exclusively, without anastomosing with the main portal system.

The constitution of the left hepatic portal vein in the current study was the same in all dissected chickens which differed than that reported by Santos et al. (2009) in domestic geese that the tributaries of the left hepatic portal vein were varied as 1, 2, 3, 4, 5 and 6 in five, three, eight, eight, three and two geese respectively.

The right hepatic vein received blood from two large veins, gastropancreaticoduodenal and common mesenteric veins Oliveira (1959) and Malinovsky (1965) in gallus, Pinto et al. (1999) in duck and El karmoty (2014) in ducks and geese. However, El karmoty (2014) in ducks and geese, added two other veins, gall bladder and duodenojejunal veins. A result which differed than our findings.

Our observations were completely similar to that found by Tolba (2015) in pigeons which revealed that the spleen was drained by the splenic veins which contributed in formation of a common trunk with the dorsal proventricular vein called the proventriculosplenic vein which was the first tributary of the right hepatic portal vein but unlike the records of El karmoty (2014) in ducks and geese that the splenic and dorsal proventricular veins joined the right hepatic portal vein separately.

Our reports in fowl differed from the results of Oliveira (1959) and Malinovsky (1965) in gallus and Tolba (2015) in pigeons that the gastropancreaticoduodenal vein was constituted only by the union of the pancreaticoduodenal and right gastric veins and of Pinto et al. (1999) in duck that this vein was formed by the pancreaticoduodenal and two right gastric veins. They also added that the pyloric vein drained into the dorsal right gastric vein. While the observations of Nishida et al. (1969) in fowl were similar to our finding that the gastropancreaticoduodenal vein was formed by the short right gastric, pancreaticoduodenal and cranial ileocecal veins.

The common mesenteric vein was constituted by the union of the cranial and caudal mesenteric veins at the duodenojejunal flexture that reported by Oliveira (1959 and Malinovsky (1965) in gallus, Pinto et al. (1999) in duck. While, El karmoty (2014) in ducks and geese, Khalifa \& Daghash (2014) in cattle egret and Tolba (2015) in pigeon confirmed that the common mesenteric vein was formed by the cranial tributaries of caudal mesenteric vein and the cranial mesenteric vein within jejunal loops.

The results of Nickel et al. (1977) in birds and Tolba (2015) in pigeon) had confirmed the absence of ileocecal vein in their study while El karmoty (2014) recorded that the ileocecal vein was a tributary drained into the cranial mesenteric vein in ducks and geese.

Our investigations in the current study were similar to that reported by Nishida et al. (1969) and Nickel et al. (1977) in fowl that the cranial mesenteric vein received a multiple arches of veins located in mesentery collecting blood from terminal parts of the caeca and the ileum but with variations in number of jejunal tributaries where Pinto et al. (1999) in duck received (12-21), El karmoty (2014) in geese received (19-21) and in ducks received (25-28) jejunal tributaries.

Our investigations in the present study confirmed the results of Purton (1969) in domestic fowl, Miyaki (1978) in fowl and Santos et al. (2009) in domestic geese that the intrahepatic right portal vein shortly divided into two large right and left branches. The right branch divided into dorsal, middle and ventral branches within the right hepatic lobe while the left branch directed medially toward the left hepatic lobe giving dorsal and ventral median branches and terminated in the left lobe by anastomosing with the left hepatic portal vein through a terminal branch.

The intrahepatic distribution of portal vein had been investigated in about 107 fowls by Miyaki (1978) who revealed different patterns of the connection between the left hepatic portal vein with the right 


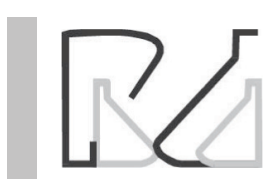

hepatic portal vein that shown as A, B, C, D, E and F. Our results had met only the pattern $E$ specially (E2a) in which the left hepatic portal vein connected to the portal venous system through a terminal anastomotic branch coming from the left branch of the right hepatic portal vein.

Our observations were similar to Purton (1969) in domestic fowl who demonstrated the macroscopically obvious interdigitation and coursing of both the intrahepatic distribution of the hepatic venous system and portal venous system. In addition to the presence of the characteristic terminal and pre-terminal twigs arose along the entire course of the large branches and the similarity in branching of the portal and hepaticvenous systems.

The present work was in agreement with that reported by Crompton \& Nesheim (1972) in domestic duck who revealed that the cystoenteric duct drained the right lobe of the liver and the hepatoenteric duct drained the left lobe of the liver and both ducts entering the distal portion of the ascending limb of the duodenum. They also added that the hepatocystic and hepatoenteric ducts joined to form a sinus. A result which was not observed in our current investigation.

Our observations in fowl resembled some observations of Crompton \& Nesheim (1972) in domestic duck; there were longitudinal folds found on the wall of the gall bladder and the common hepatoenteric duct below the sinus which was seen to be distended and possessed a few striations which looked like the folds of the wall of the gallbladder.

Our observations in the present study differed from what was reported by Turk (1982) and Bezuidenhout (1986) in ostriches, that there was no gall bladder and presented a single hepatoenteric duct that released bile into the descending duodenum and from what was reported by Nickel et al. (1984) in pigeons, that also had no gall bladder and presented two hepatoenteric ducts; a right one that opened into the ascending duodenum and a left duct that opened into the descending duodenum.

The extrahepatic bile ducts in galliforms and anatids consisted of the hepatoenteric duct that conveyed bile from the left lobe to the ascending duodenum, the hepatocystic duct that brought bile from the right lobe to the gall bladder and the cysticoenteric duct that conveyed bile from the gall bladder to the ascending duodenum Botte \& Pelagalli (1982); Sisson \& Grossman (1982), Nickel et al. (1984); Liu et al. (1998). Results which were similar to our findings in fowl.
Descriptive Anatomy of Hepatic and Portal Veins with Special Reference to Biliary Duct System in Broiler Chickens (Gallus gallus domesticus): A Recent Illustration

\section{CONCLUSION}

The right lobe of the liver was larger than the left one and undivided while the left lobe was nearly smaller and divided into dorsal and ventral divisions. The left hepatic portal vein drained the proventriculus and gizzard through five distinct tributaries; the ventral proventricular, left proventricular, ventral gastric, left gastric and pyloric veins. The pars transversa was the direct continuation of the left branch of the intrahepatic right portal vein which terminated in the left lobe into three smaller veins, the middle of them anastomosed with the left hepatic portal vein. The right proventricular vein was found in $50 \%$ of the cases which received a dorsal gastric branch, this latter branch anastomosed caudally with the dorsal tributary of the right gastric vein. A characteristic imaginary trapezoid shape was formed by the tributaries of ventral division of right gastric vein, the ventral division of the left gastric vein and the ventral gastric vein of the left hepatic portal vein drain the caudoventral part of the gizzard. There was a cranial ileocecal vein which was a tributary of the gastropancreaticoduodenal vein, a caudal ileocecal vein which was a tributary ofthe pancreaticoduodenal vein and the ileocecal tributary of the cranial mesenteric vein. The hepatic venous system was represented by right, middle and left hepatic veins in addition to umbilical and accessory hepatic veins. There were three hepatic ducts collecting bile from the right hepatic lobe, the dorsal, middle and ventral; the middle duct connected with the gall bladder while the left hepatic lobe delivered bile through only dorsal and ventral hepatic ducts. These five ducts ended medially at a sinus. The wall of the gall bladder and the common hepatoenteric duct were characterized by the presence of well-defined longitudinal folds or striations.

\section{REFERENCES}

Aho P. The world's commercial chicken meat and egg industries. In: Bell DD, Weaver WD. Commercial Chicken Meat and Egg production. $5^{\text {th }}$ ed Dordrecht: Kluwer Academic Publishers; 2001. p.3-17.

Aho P. Challenges and opportunities for marketing poultry products in developed and developing countries. Bucareste: The American Soybean Association; 2004

Al-A'Aaraji AS. Study of some anatomical and histological characteristics in liver of male indigenous turkey (Meleagris gallopava). Basrah Journal of Veterinary Research 2015;14(2):150-157.

Baumel JJ, King AS, Lucas AM, Breazile JE,Evans HE. Nomina anatomica svium: an annoted anatomical dictionary of birds. London: Academic Press; 1979

Baumel JJ, King SA, Breasile JE, Evans HE, Berge JCV. Nomina anatomica avium. Cambridge: Nuttall Ornithological Club; 1993. 
Bezuidenhout AJ. The topography of the thoraco-abdominal viscera in the ostrich (Struthio Camelus L.). Onderstepoort Journal of Veterinary Research 1986;53(2):111-117.

Botte V,Belagalli GV. Anatomia funzionale de gliuccelli domestici. Milano: Edi Ermes; 1982.

Caceci T. Avian digestive system. New York: Academic Press; 2006; p.1-94.

Crompton DWT, Nesheim MC. A Note on the biliary system of the domestic duck and a method for collecting bile. Journal of Experimental Biology 1972;S6:545-55

Dukes HH, Swenson MJ, Reece WO. Fisiologia dos animais domésticos. Rio de Janeiro: Guanabara Koogan; 1996.

El karmoty AF. Some morphological studies of the digestive system in ducks and geese with special reference to its blood supply [PhD thesis]. Gizé (EGY): Faculty of Veterinary Medicine Anatomy Department, Cairo University; 2014

El Karmoty AF, Tolba AR. Angioarchitectural Study on the Intrahepatic Blood Supply of Geese (Anser Anser Domesticus) with Special Reference to its Biliary System. Appro Poult Dairy \& Vet Sci. 6(1). APDV.000630.2019. DOI: 10.31031/APDV.2019.06.000630.

EL Gammal SMM. Anatomical studies on the blood vessels of the gastrointestinal tract of the Turkey, with Special Reference to the Hepatic Portal System and Biliary Elimination of some Drugs. PhD Thesis, 2016, Fac Vet Med, Cairo University, Egypt.

Hussein AJ, Hussein DM. Morphological and histomorphological comparative study of the liver in adult female domestic fowl (Gallus gallus), common moorhen (Gallinulachloropus) in south Iraq. Kufa Journal for Veterinary Medical Science 2016;7(1):36-45.

Ibrahim RS, Hussein AA,Al-kelaby WJ. Histomorphological study of the liver in local moorhen birds (Gallinula chloropus). Kufa Journal for Veterinary Medical Science 2016;7(2):187-192.

Khaleel IM, Al-Khazraji KI, AL-Aameli MH.A Comparative Study in some Morphological and Histological Features of the Liver in Gull (Laruscanus) and Mallard duck (Anas platyrhynchos). Advances in Animal and Veterinary Science 2017;5(7):307-311.

Khalifa EF, Daghash SM. Gross anatomical study on the tributaries of the hepatic portal vein in cattle egret (Bubulcus ibis). Veterinary Medical Journal-Giza (VMJG), 2014, Vol. 60(2), 75-90.

Kolb E. Fisiologia veterinária. Rio de Janeiro: Guanabara Koogan; 1984. p.191-197.

Liu Z, Sakamoto T, Ezure T, Yokomuro S, Murase N, Michalopoulos G, et al. Interleukin-6, hepatocyte growth factor, and their receptors in biliary epithelial cells during a type I ductular reaction in mice: interactions between the periductal inflammatory and stromal cells and the biliary epithelium. Hepatology 1998;28(5):1260-1268.

Malinovsky L. A contribution to the comparative anatomy of vessels in the abdominal part of body cavity in birds. II. A comparison of the vascular to the stomachs and adjacent organs of the buzzard (Buteo buteo L.) and domestic pigeon (Columbia livia L., f. domestica). Folia Morphologica 1965;13:202-211.

McLelland J. Digestive system. In: King AS, McLelland J, editors. Form and function in birds. London: Academic Press; 1989. v.2, p.69-181.
Miyaki T. The afferent venous vessels to the liver and the intrahepatic portal distribution in the fowl. Zentralblatt für Veterinärmedizin. Reihe C, Anatomie, Histologie, Embryologie 1978;7:129-139.

Nickel R, Schummer A, Seiferle E. Anatomy of the domestic birds. Berlin: Verlag Paul Parey; 1977. p.50-86.

Nickel R, Schummer A,Seiferle E.Trattato di anatomiadeglidomestici, 1984; Vol. V Casa Editrice Ambrosiana Milano.

Nishida T, Paik Y, Yasuda M. Comparative and topographical anatomy of the fowl. LVIII. Blood vascular supply of the glandular stomach (ventriculus glandularis) and the muscular stomach (ventriculus muscularis). Japonese Journal of Veterinary Science 1969;31:52-70.

Oliveira D. Coração e vasossangüíneos das aves. In: Getty R. Sisson/ Grossman anatomia dos animais domésticos. $5^{\text {th }}$ ed. Rio de Janeiro: Guanabara Koogan; 1959; v. 2, p.1842-1880.

Pavaux CL, JollyA. Notesurlastructurevasculo-canaliculairedufoiedesoiseauxd Pinto M.R.A., Ribeiro A.A.C.M., Souza W.M., Miglino M.A. \& Machado.

Pavaux CL, Jolly A. Note sur la structure vasculo-canaliculaire du foie des oiseaux domestiques. Revue Médicine Véterinaire 1968;119(5):445466

Pinto MRA, Ribeiro AACM, Souza WM, Miglino MA, Machado MRF. Estudo do sistema portal hepático no pato doméstico (Cairinamoshata). Brazilian Journal of Veterinary Research and Animal Science 1999:36(4):173-177.

Purton MD. Structure and ultrastructure of the liver in the domestic fowl Gallus gallus. Journal of Zoology 1969;159:273-282

Roenigk WP. World poultry consumption. Poultry Science1999;78:722-728.

Santos TC, Borba CCF, Menconi A, Maia MO, Bombonatto PP, Pereira $\mathrm{CCH}$. Veias do sistema porta-hepático em gansos domésticos. Pesquisa Veterinaria Brasileira 2009;29(4):327-332.

Schmidt RE, Reavill DR, Phalen DN. Pathology of pet and aviary birds Hoboken: Blackwell Publishing Company; 2003. p. 67

Sisson S., Grossman JD.Anatomia degli animali domestici. Padova: Piccin Editore; 1982. v.2.

Stornelli MR, Ricciardi MP, Giannessi E, Coli A. Morphological and histological study of the ostrich (Struthio camelus L.) liver and biliary system. Italian Journal of Anatomy and Embryology 2006;111(1):1-7.

Tolba AR. Gross Anatomical study on the hepatic portal vein tributaries in the common domestic pigeon "Columba Livia Domestica". International Journal of Veterinay Science 2015;4(2):63-68.

Turk DE. The anatomy of the avian digestive tract as related to feed utilization. Poultry Science 1982;61:1225-1244.

USDA. Livestock and poultry: world markets and trade [cited 2006 Mar]. Available from: https://www.fas.usda.gov/data/livestock-and-poultryworld-markets-and-trade.

Whitlow GG. Gastrointestinal anatomy and physiology. Avian physiology. $5^{\text {th }}$ ed. Honoiula: Academic Press; 2000. p.299-304. 


\section{LEGENDS OF FIGURES}

\begin{tabular}{|c|c|c|}
\hline 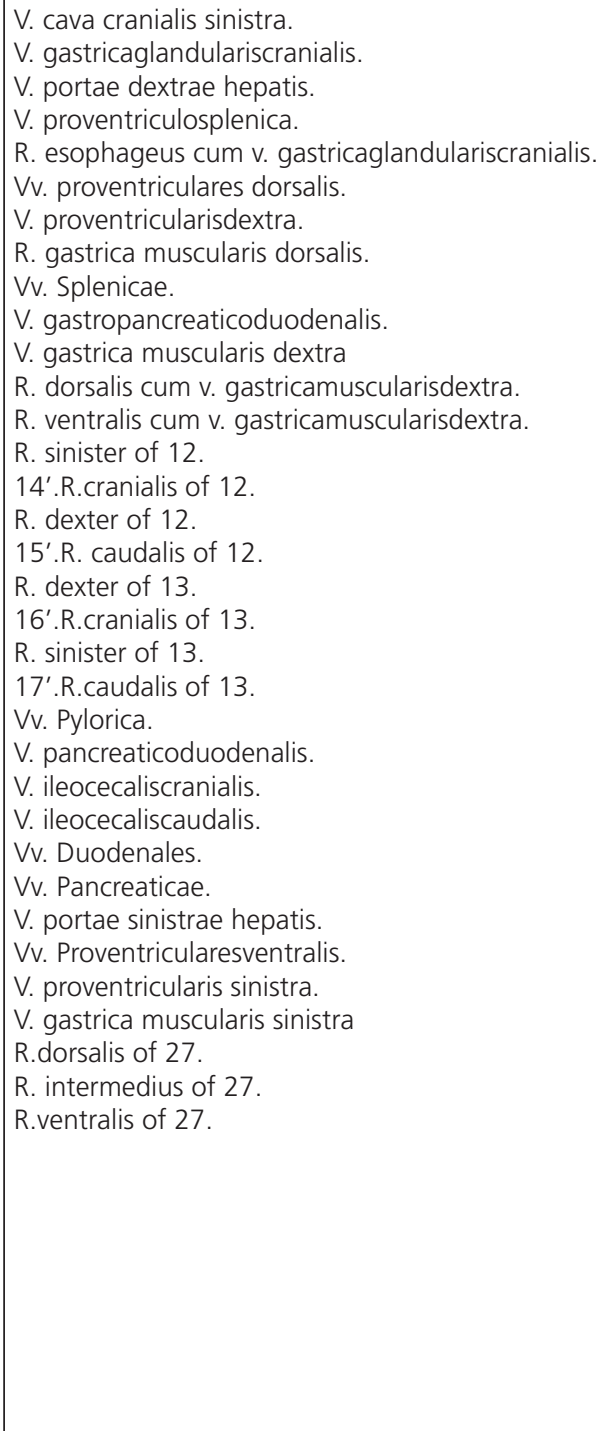 & $\begin{array}{l}\text { V. gastrica muscularis ventralis. } \\
\text { R. dexter of } 31 . \\
\text { R. sinister of } 31 . \\
\text { V. pylorica of } 24 . \\
\text { V. mesentericacommunis. } \\
\text { V. mesentericacranialis. } \\
\text { Vv. Jejunales. } \\
\text { Vv. Ileae. } \\
\text { V. lleocecalis (39'. lleal - 39". Cecal) } \\
\text { V. mesentericacaudalis (v. coccygomesenterica). } \\
\text { Rdx. cranialis cum V. mesentericacaudalis (vv. } \\
\text { lleocecales). } \\
\text { Ramusdexter v. portaedextrae. } \\
\text { Rr. Dorsales of } 42 . \\
\text { Rr. Ventrales of } 42 . \\
\text { Ramussinister v. portaedextrae. } \\
\text { Pars transversa. } \\
\text { Rr. Medianidorsales of } 46 . \\
\text { Rr. Medianiventrales of } 46 . \\
\text { Rr. Dorsales. } \\
\text { Pars anastomotica. } \\
\text { Rr. Ventrales. } \\
\text { Rr. Laterales cum v. portae sinistra. } \\
\text { Rr. Ventrales cum v. portae sinistra. } \\
\text { V. cavaecaudalis. } \\
\text { V. hepatica dextra. } \\
\text { Rdx. Dorsocranialis. } \\
\text { Rdx. Dorsocaudalis. } \\
\text { Rdx. Ventralis. } \\
\text { Vv. Hepaticaemedianae. } \\
\text { V. hepatica sinistra. } \\
\text { Rdx. Dorsocranialis. } \\
\text { Rdx. Dorsocaudalis. } \\
\text { Rdx. Ventralis. } \\
\text { V. umbilicalis. } \\
\text { V. hepatica accessoria. }\end{array}$ & $\begin{array}{l}\text { Esophagus. } \\
\text { Proventriculus gastris. } \\
\text { Isthmus gastris. } \\
\text { Ventriculus gastris. } \\
\text { d1. M. tenuis craniodorsalis. } \\
\text { d2. M. tenuis caudoventralis. } \\
\text { d3. M. crassuscaudodorsalis. } \\
\text { d4. M. crassuscranioventralis. } \\
\text { d5. Centrum tendineum. } \\
\text { Pars pylorica. } \\
\text { Sulcus caudalis. } \\
\text { Sulcus cranialis. } \\
\text { Pars descendensduodeni. } \\
\text { Flexuraduodeni. } \\
\text { Pars ascendensduodeni. } \\
\text { Flexuraduodenojejunalis. } \\
\text { Jejunum. } \\
\text { lleum. } \\
\text { Cecum. } \\
\text { Colorectum. } \\
\text { Cor. } \\
\text { Splen. } \\
\text { Pancreas. } \\
\text { Hepar. } \\
\text { s1. Lobus hepatis dexter. } \\
\text { s2. Lobus hepatis sinister. } \\
\text { s3. Pars lateralis. } \\
\text { s4. Pars medialis. } \\
\text { s5. Pars interlobaris. } \\
\text { s6. Incisura cranialis. } \\
\text { s7. Incisura caudalis. } \\
\text { Vesicabiliaris. } \\
\text { Ductus hepaticus sinister. } \\
\text { u1. Dorsal duct. } \\
\text { u2. Ventral duct. } \\
\text { Ductus hepaticus dexter. } \\
\text { v1. Dorsal duct. } \\
\text { v2. Middle duct. } \\
\text { v3. Ventral duct. } \\
\text { Ductus hepatocysticus. } \\
\text { Ductus hepatoentericuscommunis. } \\
\text { Ductus cysticoentericus. } \\
\text { Sinus. }\end{array}$ \\
\hline
\end{tabular}




\section{ERRATAS}

In the article Descriptive Anatomy of Hepatic and Portal Veins with Special Reference to Biliary Duct System in Broiler Chickens (Gallus gallus domesticus): A Recent Illustration, Doi: 10.1590/1806-9061-2019-0980, published in the Revista Brasileira de Ciência Avícolas/Brazilian Journal of Poultry Science, v21 (2):001-012, in page 011 where it was written:

\section{LEGENDS OF FIGURES}

V. cava cranialis sinistra.

V. gastricaglandulariscranialis.

V. portae dextrae hepatis.

$\checkmark$. proventriculosplenica.

R. esophageus cum v. gastricaglandulariscranialis

$\mathrm{V} v$. proventriculares dorsalis.

V. proventricularisdextra.

R. gastrica muscularis dorsalis.

Vv. Splenicae.

V. gastropancreaticoduodenalis.

V. gastrica muscularis dextra

R. dorsalis cum v. gastricamuscularisdextra.

$R$. ventralis cum $v$. gastricamuscularisdextra.

R. sinister of 12 .

$14^{\prime}$.R.cranialis of 12 .

R. dexter of 12.

$15^{\prime}$.R. caudalis of 12 .

R. dexter of 13 .

$16^{\prime}$.R.cranialis of 13 .

R. sinister of 13

$17^{\prime}$.R.caudalis of 13 .

Vv. Pylorica.

V. pancreaticoduodenalis

V. ileocecaliscranialis.

V. ileocecaliscaudalis.

Vv. Duodenales.

Vv. Pancreaticae.

V. portae sinistrae hepatis.

Vv. Proventricularesventralis.

V. proventricularis sinistra.

V. gastrica muscularis sinistra

R. dorsalis of 27.

R. intermedius of 27.

R.ventralis of 27
$\mathrm{V}$. gastrica muscularis ventralis.

R. dexter of 31 .

R. sinister of 31 .

V. pylorica of 24 .

V. mesentericacommunis.

V. mesentericacranialis.

Vv. Jejunales.

Vv. Ileae.

V. Ileocecalis (39'. Ileal - 39". Cecal)

$\mathrm{V}$. mesentericacaudalis ( $\mathrm{v}$. coccygomesenterica).

$\mathrm{Rdx}$. cranialis cum v. mesentericacaudalis (vv. lleocecales).

Ramusdexter v. portaedextrae.

Rr. Dorsales of 42.

Rr. Ventrales of 42 .

Ramussinister $\mathrm{v}$. portaedextrae.

Pars transversa.

Rr. Medianidorsales of 46 .

Rr. Medianiventrales of 46

Rr. Dorsales.

Pars anastomotica.

Rr. Ventrales.

Rr. Laterales cum v. portae sinistra.

Rr. Ventrales cum v. portae sinistra.

V. cavaecaudalis.

V. hepatica dextra.

$\mathrm{Rdx}$. Dorsocranialis.

Rdx. Dorsocaudalis.

Rdx. Ventralis.

Vv. Hepaticaemedianae.

V. hepatica sinistra.

$\mathrm{Rdx}$. Dorsocranialis.

Rdx. Dorsocaudalis.

Rdx. Ventralis.

V. umbilicalis.

V. hepatica accessoria.
Esophagus.

Proventriculus gastris.

Isthmus gastris.

Ventriculus gastris.

d1. M. tenuis craniodorsalis.

d2. M. tenuis caudoventralis.

d3. M. crassuscaudodorsalis.

d4. M. crassuscranioventralis.

d5. Centrum tendineum.

Pars pylorica.

Sulcus caudalis.

Sulcus cranialis.

Pars descendensduodeni.

Flexuraduodeni.

Pars ascendensduodeni.

Flexuraduodenojejunalis.

Jejunum.

lleum.

Cecum.

Colorectum.

Cor.

Splen.

Pancreas.

Hepar.

s1. Lobus hepatis dexter.

s2. Lobus hepatis sinister.

s3. Pars lateralis.

s4. Pars medialis.

s5. Pars interlobaris.

s6. Incisura cranialis.

s7. Incisura caudalis.

Vesicabiliaris.

Ductus hepaticus sinister.

u1. Dorsal duct.

u2. Ventral duct.

Ductus hepaticus dexter.

v1. Dorsal duct.

v2. Middle duct.

v3. Ventral duct.

Ductus hepatocysticus.

Ductus hepatoentericuscommunis.

Ductus cysticoentericus.

Sinus. 


\section{LEGENDS OF FIGURES}

1. V. cava cranialis sinistra.

2. V. gastrica glandularis cranialis.

3. V. portae dextrae hepatis.

4. V. proventriculosplenica.

5. R. esophageus cum v. gastrica glandularis

cranialis.

6. Vv. proventriculares dorsalis.

7. V. proventricularis dextra.

8. R. gastrica muscularis dorsalis.

9. Vv. Splenicae.

10. V. gastropancreaticoduodenalis.

11. V. gastrica muscularis dextra

12. R. dorsalis cum v. gastrica muscularis dextra.

13. R. ventralis cum v. gastrica muscularis dextra.

14. R. sinister of 12 .

$14^{\prime}$.R. cranialis of 12 .

15. R. dexter of 12 .

$15^{\prime}$. R. caudalis of 12 .

16. R. dexter of 13 .

$16^{\prime}$.R. cranialis of 13 .

17. R. sinister of 13 .

$17^{\prime}$.R. caudalis of 13 .

18. Vv. Pylorica.

19. V. pancreaticoduodenalis.

20. V. ileocecalis cranialis.

21. V. ileocecalis caudalis.

22. Vv. Duodenales.

23. Vv. Pancreaticae.

24. V. portae sinistrae hepatis.

25. Vv. Proventriculares ventralis.

26. V. proventricularis sinistra.

27. V. gastrica muscularis sinistra

28. R.dorsalis of 27.

29. R. intermedius of 27.

30. R.ventralis of 27
31. V. gastrica muscularis ventralis.

32. R. dexter of 31.

33. R. sinister of 31.

34. V. pylorica of 24

35. V. mesenterica communis.

36. V. mesenterica cranialis.

37. Vv. Jejunales.

38. Vv. lleae

39. V. Ileocecalis (39'. Ileal - 39". Cecal)

40. V. mesenterica caudalis (v. coccygomesenterica)

41. Rdx. cranialis cum v. mesenterica caudalis (vv lleocecales).

42. Ramus dexter v. portae dextrae.

43. Rr. Dorsales of 42.

44. Rr. Ventrales of 42

45. Ramus sinister v. portae dextrae.

46. Pars transversa.

47. Rr. Mediani dorsales of 46.

48. Rr. Mediani ventrales of 46 .

49. Rr. Dorsales.

50. Pars anastomotica.

51. Rr. Ventrales.

52. Rr. Laterales cum v. portae sinistra.

53. Rr. Ventrales cum v. portae sinistra.

54. V. cavae caudalis.

55. $V$. hepatica dextra.

56. Rdx. Dorsocranialis.

57. Rdx. Dorsocaudalis.

58. Rdx. Ventralis.

59. Vv. Hepaticae medianae.

60. V. hepatica sinistra.

61. Rdx. Dorsocranialis.

62. Rdx. Dorsocaudalis.

63. Rdx. Ventralis.

64. V. umbilicalis.

65. V. hepatica accessoria. a. Esophagus.

b. Proventriculus gastris.

c. Isthmus gastris.

d. Ventriculus gastris.

d1. M. tenuis craniodorsalis.

d2. M. tenuis caudoventralis.

d3. M. crassus caudodorsalis.

d4. M. crassus cranioventralis.

d5. Centrum tendineum.

e. Pars pylorica.

f. Sulcus caudalis.

g. Sulcus cranialis.

h. Pars descendens duodeni.

i. Flexura duodeni.

j. Pars ascendens duodeni.

k. Flexura duodenojejunalis.

I. Jejunum.

m. lleum.

n. Cecum

o. Colorectum.

p. Cor.

q. Splen.

r. Pancreas.

s. Hepar.

s1. Lobus hepatis dexter.

s2. Lobus hepatis sinister.

s3. Pars lateralis.

s4. Pars medialis.

s5. Pars interlobaris.

s6. Incisura cranialis.

s7. Incisura caudalis.

t. Vesica biliaris

u. Ductus hepaticus sinister.

u1. Dorsal duct.

u2. Ventral duct.

v. Ductus hepaticus dexter.

v1. Dorsal duct.

v2. Middle duct.

v3. Ventral duct.

w. Ductus hepatocysticus.

$x$. Ductus hepatoentericus communis.

y. Ductus cysticoentericus.

z. Sinus. 